\title{
Demography of Grazed Tussock Grass Populations in Patagonia
}

\author{
Gabriel Oliva, ${ }^{1}$ Marta Collantes, ${ }^{2}$ and Gervasio Humano ${ }^{3}$

\begin{abstract}
Authors are ${ }^{1}$ Researcher at Instituto Nacional de Tecnología Agropecuaria (INTA), EEA Santa Cruz, Argentina, and Assistant Farmacológicos y Botánicos, CONICET, and Professor of the University of Buenos Aires, Buenos Aires, Argentina; and

${ }^{3}$ Technician of Universidad Nacional de la Patagonia Austral, Rio Gallegos, EEA Santa Cruz, Argentina.
\end{abstract} \\ Professor, Universidad Nacional de la Patagonia Austral, Rio Gallegos, Santa Cruz, Argentina; ${ }^{2}$ Researcher of Centro Estudios
}

\begin{abstract}
The cover of Festuca gracillima (coirón fueguino), a native tussock grass that dominates grass steppes of Southern Patagonia and Tierra del Fuego, has diminished under continuous sheep grazing. This loss is a concern, because it also reduces forage availability in winter, biodiversity, and soil stability. In the present study, the hypothesis that tussock grass birth and mortality rates are balanced only under moderate-grazing or exclusion regimes was tested with two 5-year records of demographic data obtained from 3 sheep grazing regimes: exclosure (no grazing), low $\left(0.0348 \mathrm{AU} \cdot \mathrm{ha}^{-1} \cdot \mathrm{y}^{-1}\right.$, where AU represents animal units equivalent to the consumption of a $450-\mathrm{kg}$ cow), and high $\left(0.1043 \mathrm{AU} \cdot \mathrm{ha}^{-1} \cdot \mathrm{y}^{-1}\right)$. Tussocks were outlined in photographs and marked in the field at two 5 -year intervals. The initial total number of plants for the 3 grazing regimes $(n=358)$ increased to 384 plants at the end of the 10-year period. No recruitment from seed was observed; plant number changed as a balance of yearly rates of tussock mortality $(1.48 \%)$, amalgamation $(0.75 \%)$, and subdivision $(2.04 \%)$. Intensely grazed populations showed greater $(2.13 \%)$ mortality rates than ungrazed $(1.20 \%)$ or moderately grazed $(0.78 \%)$ populations. Tussocks in intensely grazed populations were smaller $\left(167 \mathrm{~cm}^{2} \cdot\right.$ plant $\left.{ }^{-1}\right)$ than those in moderately grazed $\left(197 \mathrm{~cm}^{2} \cdot\right.$ plant $\left.^{-1}\right)$ or ungrazed $\left(300 \mathrm{~cm}^{2} \cdot\right.$ plant $^{-1}$ ) populations. Transition matrices showed eigenvalues of 0.701 (high grazing), 0.794 (exclosure), and 0.876 (low grazing). All growth rates of demographic models were negative; the largest rate of population decrease was found under high-intensity grazing, for which projections show that half the tussocks would be lost in 37 years. Under low-intensity grazing and exclosure, a similar tussock loss would take place in 87 and 74 years, respectively. Results show 1) the importance of vegetative processes for tussock demography, 2) the extremely slow dynamics of population changes, and 3) that tussocks may suffer increased mortality as a consequence of subdivision or fragmentation, a process that can be viewed as a small-scale example of the generalized effect of patch subdivision under grazing.
\end{abstract}

\section{Resumen}

Festuca gracillima (coirón fueguino) es una gramínea mediana dominante en los pastizales del sur de la Patagonia y norte de Tierra del Fuego que ha ido perdiendo cobertura bajo pastoreo continuo. El proceso implica también una reducción en el forraje disponible en invierno, en la estabilidad del suelo y en la biodiversidad. El presente trabajo analiza 10 años de demografía de poblaciones de coirones sujetos a pastoreo controlado con tres intensidades: clausura (sin pastoreo), alta $(0.1043$ $\mathrm{AU} \cdot \mathrm{ha}^{-1} \cdot \mathrm{año}^{-1}$, AU son unidades animales equivalentes al consumo de una vaca de $\left.450 \mathrm{~kg}\right)$, y baja $\left(0.0348 \mathrm{AU} \cdot \mathrm{ha}^{-1} \cdot \mathrm{año}^{-1}\right)$. Se puso a prueba la hipótesis de que las tasas de natalidad y mortalidad llegan al equilibrio solamente bajo pastoreo moderado o en exclusión. Los coirones fueron identificados en mapas fotográficos y marcados en el campo en dos períodos consecutivos de cinco años. La población inicial de 358 plantas cambió lentamente, dando lugar a 384 individuos al cabo de diez años. No se observó reclutamiento por semilla, y el número de individuos varió de acuerdo al balance entre tasas anuales de mortalidad $(1.48 \%)$, fusión $(0.75 \%)$ y subdivisión $(2.04 \%)$ vegetativa. Las poblaciones bajo alta carga animal mostraron mayores tasas anuales de mortalidad $(2.13 \%)$ que las de áreas clausuradas $(1.20 \%)$ o las moderadamente pastoreadas $(0.78 \%)$. Los coirones de áreas pastoreadas fueron más pequeños $\left(167 \mathrm{~cm}^{2} \cdot\right.$ planta $\left.^{-1}\right)$ que los de áreas pastoreadas moderadamente (197 $\mathrm{cm}^{2} \cdot$ planta $\left.^{-1}\right)$ o las clausuradas $\left(300 \mathrm{~cm}^{2} \cdot\right.$ planta $\left.^{-1}\right)$. Las matrices de transición muestran autovalores de 0.701 (alta carga), 0.794 (clausura), y 0.876 (baja carga). Todas las tasas de crecimiento poblacional asociadas son negativas. Las proyecciones muestran caídas más marcadas en las poblaciones bajo altas cargas, que perderían un $50 \%$ de sus individuos en 37 años, mientras que las sujetas a bajas cargas animales y clausura llegarían a una caída similar en un plazo de 74 y 87 años, respectivamente. Los resultados señalan 1) la importancia de la reproducción vegetativa en la demografía de estos coirones, 2) una dinámica poblacional extremadamente lenta, 3) que los coirones pueden sufrir mayor mortalidad por fragmentación, un ejemplo en pequeña escala el efecto generalizado de subdivisión de parches que el pastoreo provoca en los ecosistemas.

Key Words: Festuca gracillima, grassland ecology, rangelands, steppe, arid ecosystems, matrix, sheep

This research was funded by INTA and UNPA Project 29A077.

Correspondence: Gabriel Oliva, EEA Santa Cruz, Convenio INTA-UNPA-Provincia de Santa Cruz, Chacra 45, CC 332, 9400 Río Gallegos, Santa Cruz, Argentina. Email: goliva@correo.inta.gov.ar

Manuscript received 2 August 2002; manuscript accepted 9 January 2005.

\section{INTRODUCTION}

The steppes surrounding the Magellan Strait, in southern continental Patagonia and northern Tierra del Fuego, are dominated by the tussock-forming grass Festuca gracillima Hook, with few scattered tall shrubs (Borrelli et al. 1997; 
Collantes et al. 1999). Sheep have grazed these rangelands continuously for more than a century, and fence-line contrast studies indicate that tussocks have lost cover in grazed paddocks, giving way to dwarf shrubs of the genera Nardophyllum and Nassauvia (Borrelli et al. 1984, 1988).

Festuca gracillima is not a preferred forage for sheep, but it constitutes about one-third of forage intake in winter, when palatable short grasses are covered with snow (Posse et al. 1996; Pelliza et al. 1997). The availability of paddocks with tussocks is critical for overwintering sheep, because farms do not usually make winter forage reserves. The presence of tussocks also is an environmental asset, because tall grasses increase soil stability (Oliva and Borrelli 1993), provide habitat for wildlife, and create refuge for palatable plant species (Faggi 1985).

Efforts to control rangeland degradation in Patagonia have concentrated on estimating the forage biomass of key species and on regulating stocking rates to keep the forage residue above critical levels (Borrelli and Oliva 1999). It is assumed that moderate consumption of preferred grasses will ensure the survival of less palatable species, such as tussocks. Nevertheless, experimental evaluation of the effect of improved management on tussock loss is limited, because the process is slow. Ten years of controlled grazing at 3 stocking rates failed to show a decrease in tussock grass cover at the community scale when grazed at high intensity (Oliva et al. 1998). Direct observation of the process may require longer and clearly nonviable experiments or unrealistically high stocking rates. A possible alternative is to analyze the problem at a smaller scale using demographic models.

Demographic theory (Harper 1980) regards populations as groups of organisms that can be counted, and it interprets their fate as a balance between birth and mortality rates. For a population to survive under a certain management scheme, each individual should produce at least one offspring during its life cycle. The application of these models in tussock grasslands is not a simple task, because individuals are not easily counted. A tussock (or plant) is, in fact, a grouping of modules (tillers), the individual origins of which are difficult to trace, because they may arise from seed or from basal meristems. The size of an individual tussock at any time is a result of the balance between its tiller birth rate and death rate. Radial growth may accrue from the aggregation of neighboring plants, and big individuals may produce new plants by fragmentation. Nevertheless, this complex demography can be modeled in a sizeclassified matrix (Caswell 1989), and the future population behavior can be analyzed by projection, given that the environmental conditions of the observation period recur indefinitely and that density-dependent processes are not active. These two assumptions are unrealistic, but such projections have been widely used as an aid to interpreting long-term trends that otherwise would be out of reach for research.

The objective of the present study was to examine the demographic dynamics of a tussock population under 3 grazing intensities. The effect of grazing in the size structure (the proportion of different size classes) and the demographic rates of the population will be interpreted under the main hypothesis that the balance between birth and death of tussocks can be attained only in moderately grazed and ungrazed populations.

\section{MATERIALS AND METHODS}

\section{Species}

Festuca gracillima is typical of the Magellanic steppe, which extends over the southern part of the Argentine province of Santa Cruz, the Chilean region of Magallanes, and northern Tierra del Fuego Island (Boelcke et al. 1985). The habitat of this tussock grass is restricted to well-drained soils on plateaus and hill slopes between Bahía de San Julian, at lat $49^{\circ} 30^{\prime} \mathrm{S}$ (personal observation), and the Beagle Channel, at lat $55^{\circ} \mathrm{S}$ (Moore 1983). Leaf blades of $F$. gracillima are usually $30 \mathrm{~cm}$ high, with clumped foliage as tillers arise from intravaginal meristems, and no rhizomes or stolons contribute to vegetative growth. Tussocks grow radially and accumulate senescent foliage that is bright yellow or gray in color. Big tussocks tend to disintegrate, leaving in place "fairy rings" of small individuals. Flowering starts in December, when panicles having 3-7 spikelets emerge. Each spikelet bears 4-6 flowers.

\section{Experimental Site}

Experimental populations were included in a grazing trial that was set up in 1986 in Estancia Moy Aike Chico, 60 km northnorthwest from Río Gallegos, Santa Cruz, Argentina (lat $51^{\circ} 47^{\prime} \mathrm{S}$, long $\left.68^{\circ} 47^{\prime} \mathrm{W}\right)$ on the sandstones of the "Santacrucense" formation (Wijnhoud and Sourrouile 1972), within the dry variant of the Magellanic steppe (Fig 1). Average rainfall is $182 \mathrm{~mm}$, with a maximum in the summer and a minimum in the early spring (Burgos 1985). Average temperatures in the summer (January) and winter (July) are $12.7^{\circ} \mathrm{C}$ and $1.4^{\circ} \mathrm{C}$, respectively (De Fina et al. 1968). Strong winds with a mean intensity of $27 \mathrm{~km} \cdot \mathrm{h}^{-1}$ are a distinct feature of the climate. The landscape consists of flat plateaus raised $100-150 \mathrm{~m}$ above sea level (Anchorena 1985). Soils are sandy, rich in organic matter in the top $10 \mathrm{~cm}$, and abundantly pebbled in deeper argilic horizons. Soils were classified as Borolic haplargids by Salazar Lea Plaza and Godagnone (1990). Vegetation in the experimental plots had 36 plant species, $44.6 \%$ total vegetation cover, and $11.4 \%$ F. gracillima cover.

\section{Climate}

Mean annual rainfall in the area, from 1986 to 1998, was 174 $\mathrm{mm}$, which is similar to the estimated mean annual rainfall of $182 \mathrm{~mm}$ in the decade of the 1950s (De Fina et al. 1968). Mean annual rainfall in the experimental periods 1989-1993 and 1994-1999 was 183 and $182 \mathrm{~mm}$, respectively. Dry years with rainfall only slightly greater than $100 \mathrm{~mm}$ were recorded in 1989 and 1995. Wet years were 1990 and 1994, with 272 and $267 \mathrm{~mm}$ of rainfall, respectively.

\section{Treatments and Design}

Tussock populations from two contiguous 40-ha paddocks and a 0.5 -ha exclosure, set in a plant community dominated by an open F. gracillima grassland with patches of dwarf Nardophyllum bryoides shrubland, were selected for the present study. The site had been grazed at 0.30-0.50 SE (sheep equivalents) $\cdot \mathrm{ha}^{-1} \cdot \mathrm{y}^{-1}$ or $0.052-0.087 \mathrm{AU}$ (animal units) $\cdot \mathrm{ha}^{-1} \cdot \mathrm{y}^{-1}$ for a century. The SE (45-kg ewe) was related to the AU (450$\mathrm{kg}$ cow) using a conversion factor of 5.75 sheep per AU (Ruyle and Ogden 1993). In 1987, a controlled, nonreplicated grazing 
trial was put in place using Corriedale wethers and 3 stocking rates: high $\left(0.60 \mathrm{SE} \cdot \mathrm{ha}^{-1} \cdot \mathrm{y}^{-1}\right.$ or $\left.0.1043 \mathrm{AU} \cdot \mathrm{ha}^{-1} \cdot \mathrm{y}^{-1}\right)$, low (0.20 SE $\cdot \mathrm{ha}^{-1} \cdot \mathrm{y}^{1}$ or $\left.0.0348 \mathrm{AU} \cdot \mathrm{ha}^{-1} \cdot \mathrm{y}^{-1}\right)$, and exclosure (no grazing).

In 1989, two 1-ha patches dominated by open grasslands (Oliva and Borrelli 1993), similar to those of the 0.5-ha exclosure, were selected in each grazed paddock. The vegetation in each patch was sampled with point-line quadrats set along 50-m-long transects. These censuses were compared with communities considered to be examples of different conditions using a floristic similarity index as suggested by Borrelli et al. (1988). The communities conformed to the "fair-good" condition. Within each of the 1-ha patches in grazed treatments or the 0.5 -ha patch in the exclosure, three $4-\times 1.20-\mathrm{m}$ plots were randomly selected and marked with steel tubes driven completely into the ground. At each sampling date, the plots were outlined with strings and photographed using a reflex camera (35 mm, 100 ASA color film, with flash) mounted on a 2-m-high tripod. Five color prints were combined to produce a photographic map of each plot. Sampling was done yearly between 1989 and 1996, and a final map was produced in 1999. The present study is based on the 1989, 1994, and 1999 maps.

Individual tussocks were outlined by visual interpretation of the photographic maps. Any tiller or group of tillers that showed at least one green leaf and was separated from other groups by $2 \mathrm{~cm}$ or more of bare soil, litter, or other species was considered to be an individual tussock. Tussock maps were drawn in the laboratory and checked in the field. Individuals were permanently marked in the field using engraved, leadheaded nails. Photographic maps were scanned, and the contour of each individual was digitized to measure its basal area. Grazed and ungrazed tussocks were treated in the same way. For biomass and density standard error estimations, each 4- $\times 1.20-\mathrm{m}$ plot was treated as a subsample, with $n=3$ for each treatment. Transition probabilities in the demographic model were estimated based on all the individuals in the three 4- $\times 1.20-\mathrm{m}$ plots of each treatment.

The relation between individual basal areas, as estimated from the photographic maps, and the biomass of tussocks was examined using a double-sampling technique. During the 1989 sampling, three additional $2-\times 1.2-\mathrm{m}$ plots were randomly placed in the vicinity of the permanent plots of the exclosure. These plots were photographed simultaneously with the permanent plots, and 100 tussocks were outlined using the technique described previously. The tussocks were identified in the field 2 weeks later and clipped to $1 \mathrm{~cm}$ in height, and the material was oven-dried to constant weight. The dry material was partitioned into "green" and "dead" components. Cover and weight were tested for normality, which was attained after using logarithmic transformation, and linear regressions were estimated. Because the fit was highly significant $\left(R^{2}=0.85\right.$, $P<0.001)$, the linear function was used to estimate tussock biomass values from basal cover values.

Differences between the first (year 1989) and last (year 1999) estimations of tussock biomass and number within treatments were assessed by contrasts computed using the "Repeated Measures ANOVA" SAS subpackage (SAS 1988). Before this analysis, tussock biomass data were normalized with log transformation. Class frequencies of demographic processes of mortality, subdivision, and amalgamation were estimated and

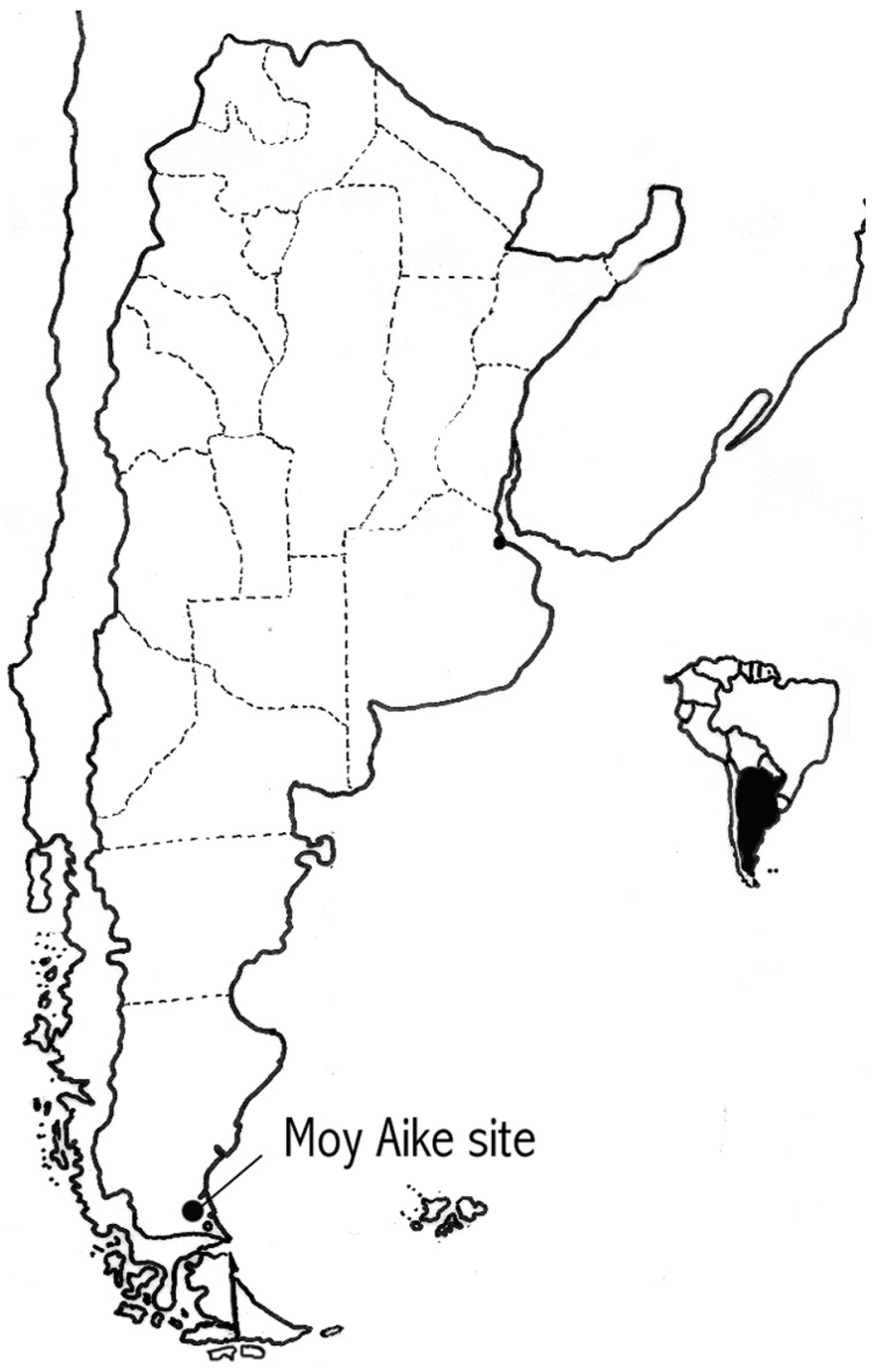

Figure 1. Location of the experimental site of Moy Aike in Santa Cruz Province, Patagonia, Argentina.

compared by two-way tables. The degree of association between plant size and demographic processes of subdivision, amalgamation, and mortality was evaluated with Pearson's chi-square statistic (SAS 1988). No inferential statistic tests between grazing treatments were done, because no replicates were available for the paddocks (Hurlbert 1984). Differences between grazing treatments are shown using descriptive statistics based on means and standard errors of the mean for the 3 plots of each treatment. These differences cannot be attributed indisputably to a grazing effect; therefore, results are interpreted with an ecological perspective (Wester 1992).

A size-classified matrix population model (Caswell 1989) was constructed. Transition probabilities (the probability of staying at a certain size class or of moving from one size class to another) were estimated for two 5-year intervals taking into account all the individuals present in the 3 plots of each treatment. Quartiles of the distribution of tussock size for the whole population in the initial year were used as limits for the four size classes. Tussocks of 1-39, 40-89, 90-199, and 200 $\mathrm{cm}^{2}$ or more were classified as small, medium, big, and very big, 


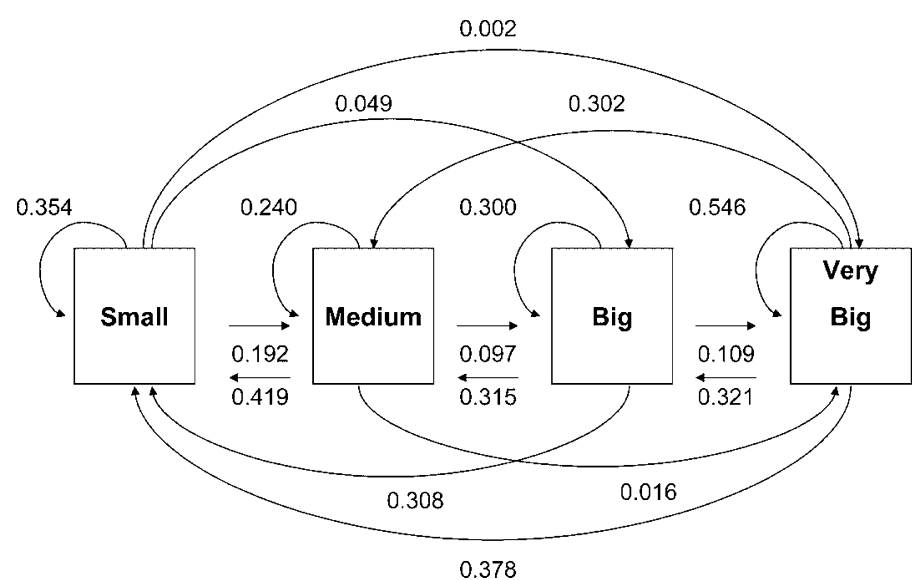

Figure 2. Diagram of the population stages and transition that were considered. Recruitment by seed was not observed in the field and, thus, was not included in the matrix population models. The probabilities correspond to the 10-year transition matrix for the whole population in Table 3.

respectively. The 4-dimensional population vectors and transition matrixes were obtained from the comparison of the 3 sequential photographic maps (years 1989, 1994, and 1999). The origin of each individual in a particular map was established on the previous map by the following processes: 1) birth by seed (not observed), 2) survival (a tussock remained in the same size group), 3) growth (a tussock increased in size, crossing the threshold between size groups), 4) subdivision (a continuous tussock is fragmented into two discrete groups of tillers). Tussocks could also disappear by the demographic processes of amalgamation (when two adjacent tussocks grew into each other and could no longer be individualized using visual criteria) and mortality (all the live tissue of a tussock disappeared, leaving the corresponding marker on the ground). These processes, along with the transition probabilities, are shown in Figure 2.

The transition frequencies between size classes were estimated and arranged in a $4 \times 4$ transition matrix for each of the two 5-year periods (1989-1994 and 1994-1999). The final transition matrix (1989-1999) for each treatment, with a projection interval of 10 years, was the product of the two 5-year matrices (see Table 3 ). The dominant eigenvalue $(\lambda)$ of each transition matrix was calculated by the power method (Caswell 1989). It represents the limit approached by the growth rate of the population, and $\ln \lambda=r$ can be considered to be the instantaneous growth rate of the population, provided that the transition frequencies remain constant. Projections were obtained for the population of each treatment. The length of time in which populations lost half the initial individuals was estimated graphically.

\section{RESULTS}

\section{Tussock Biomass}

Green tussock biomass standing crop in the heavily grazed and ungrazed treatments decreased $(P<0.05)$ over the 10 -year period examined (Fig. 3). Tussock biomass differences between
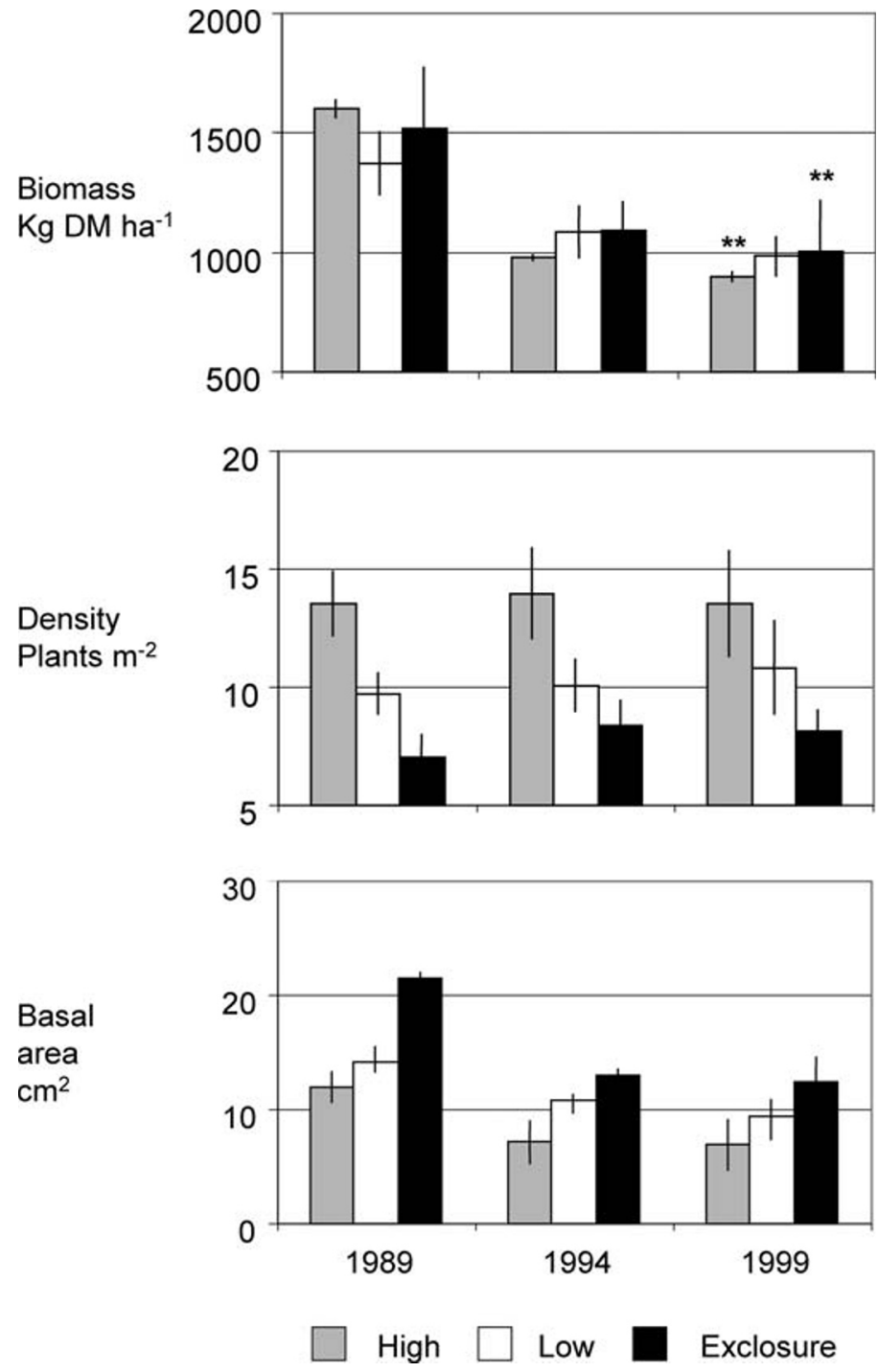

Figure 3. Live biomass, number, and mean basal area of tussocks as estimated from photographic maps in the 3 grazing treatments. Lines represent standard errors of the mean $(n=3)$. Stars indicate significant differences for that treatment in repeated-time analysis-of-variance contrasts (1989 vs. 1994).

treatments could not be statistically tested, but the means did not differ markedly between grazing treatments.

\section{Tussock Number}

Tussock density did not change $(P>0.05)$ over the 10 -year period (Fig. 3). Recruitment by seed was zero, and the individuals that disappeared by mortality or amalgamation were replaced by new individuals generated by subdivision.

Tussock densities in the high-intensity grazing treatment doubled those in the exclosure. This difference was consistent throughout the present study, and the number of tussocks did not change significantly within treatments (Fig. 3). Initial differences and the lack of replications restrict the statistical evaluation of these differences.

The smallest tussocks were consistently found under highgrazing conditions, and the biggest were found in the exclosure. 
Table 1. Initial and final estimations of population $N$ (number of tussocks) in the populations subjected to high and low stocking rates and exclosure treatments. Intermediate columns show the number of individuals that died, subdivided into two or more tussocks, or amalgamated with neighboring plants during the 10-year period.

\begin{tabular}{lccccc}
\hline $\begin{array}{l}\text { Stocking } \\
\text { treatment }\end{array}$ & $\begin{array}{c}\text { Initial } \\
\text { population }\end{array}$ & Died & Subdivided & Amalgamated & $\begin{array}{c}\text { Final } \\
\text { population }\end{array}$ \\
\hline High & 160 & 34 & 33 & 13 & 160 \\
Low & 115 & 9 & 20 & 7 & 128 \\
Exclosure & 83 & 10 & 20 & 7 & 96 \\
Total & 358 & 53 & 73 & 27 & 384 \\
\hline
\end{tabular}

Mean tussock size showed a nonsignificant decrease over the 1989-1999 period (Fig. 3).

\section{Demographic Processes in the Entire Population}

The balance of the vegetative processes of amalgamation and subdivision gave way to a slight $(P>0.05)$ increase of total population (Table 1). Mean yearly mortality rates were low $(1.48 \%$ ) (Table 2$)$, and they seemed to vary between treatments. The significance of these differences, however, could not be evaluated. Maximum rates were reached under the highgrazing treatment (Table 2 ).

Subdivision rates also seemed to differ between grazing treatments, and they were higher in the exclosure. The population under high-intensity grazing showed an intermediate subdivision rate. Amalgamation rates seemed to be unaffected by grazing treatments (Table 2 ).

\section{Demographic Processes in Relation to Size Classes}

Plant mortality was different among tussock size classes $\left(\chi^{2}=35.07, P<0.001\right)$. Small and medium tussocks showed the greatest mortality rates (Fig. 4). Mortality within a size class does not seem to differ among grazing treatments. Small tussocks suffered $3.51 \%$ mortality under high grazing, $4.00 \%$ under low grazing, and $3.33 \%$ under exclosure. Mean mortality rates of big or very big tussocks were the smallest, at $0.16 \%$.

Subdivision rates also were influenced by tussock size $\left(\chi^{2}=129.17, P<0.001\right)$. Bigger tussocks showed higher subdivision rates (Fig. 4). The highest subdivision rates were observed in very big tussocks under high-intensity grazing. Tussocks in the ungrazed population subdivided at an annual rate of $4.15 \%$, whereas those under low-intensity grazing subdivided at a rate of $2.75 \%$. Amalgamation rates were not influenced by tussock size $\left(\chi^{2}=2.48, P<0.48\right)$.

\section{Matrix Population Model: Final Transition Matrices}

Final transition matrices (years 1989-1999) summarize the dynamics of the two 5-year transition matrices and are presented in Table 3. The entire population shows an eigenvalue $(\lambda)$ smaller than 1, with a corresponding negative $r$ value (Table 4). With these parameters, the population would eventually disappear.

\section{DISCUSSION}

The demography of F. gracillima in the Moy Aike site was controlled by vegetative growth processes. No incorporation of
Table 2. Yearly mortality, subdivision, and amalgamation rates (\% initial population that undergoes the demographic process each year). Rates were calculated based on population change over 10 years and then divided to obtain yearly figures.

\begin{tabular}{lccc}
\hline Stocking treatment & Mortality & Subdivision & Amalgamation \\
\hline High & 2.13 & 2.06 & 0.81 \\
Low & 0.78 & 1.74 & 0.61 \\
Exclosure & 1.20 & 2.41 & 0.84 \\
Total & 1.48 & 2.04 & 0.75 \\
\hline
\end{tabular}

tillers by seed was observed, even though other studies have shown that the species produces copious seed rains of as much as 640 viable caryopsis $\cdot \mathrm{m}^{-2}$ together with seedling survival of as much as $7 \%$ after a rainy year (Oliva 1996). Competition with adult plants probably blocks the final recruitment of surviving seedlings, but an occasional input of plants by sexual reproduction should not be ruled out.

Observed tussock mortality rates correspond to long life spans, and the matrix models show that even without considering eventual plant establishment from seed sources, populations would be able to persist for a long time based on their
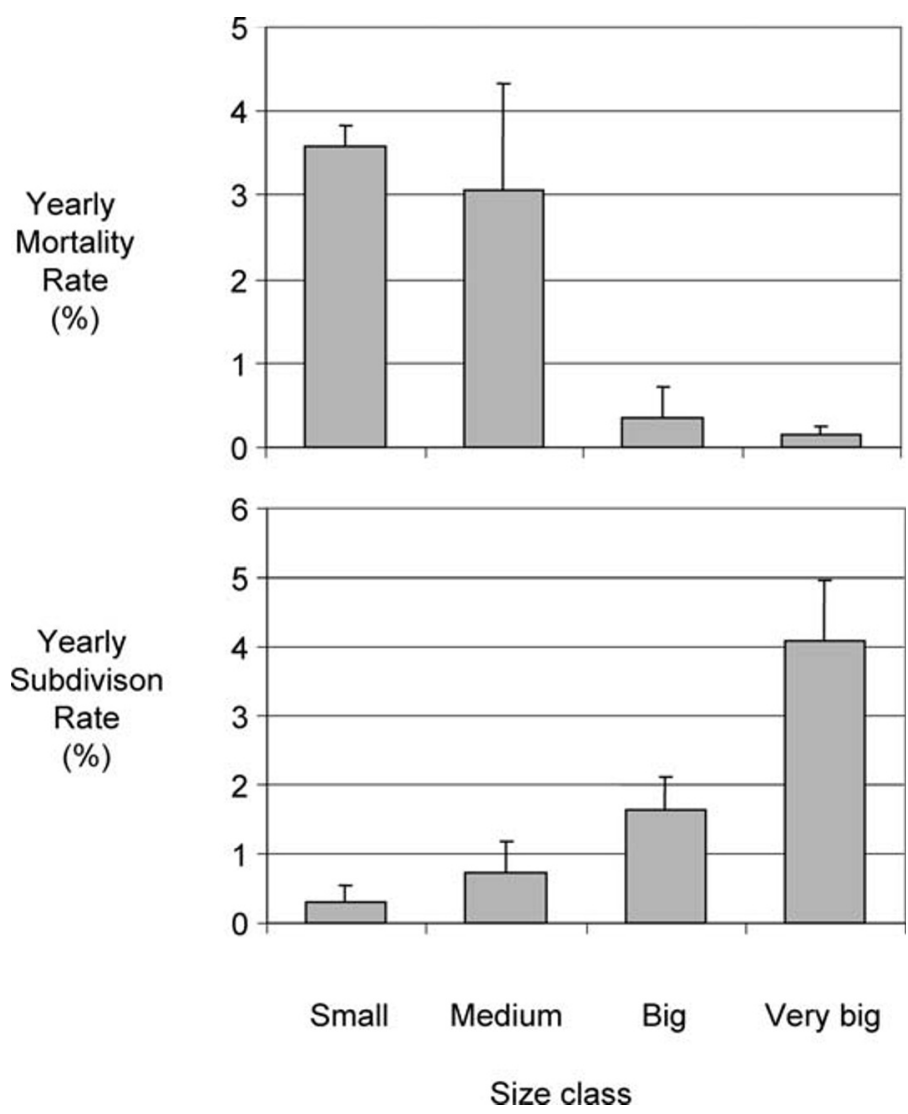

Figure 4. Yearly mortality and subdivision rates of tussocks classified by size. Means and standard errors of the mean of the populations under different grazing treatments $(n=3)$ are shown. Tussocks of $1-39 \mathrm{~cm}^{2}$ of basal cover are considered to be small, those of $40-89 \mathrm{~cm}^{2}$ to be medium, those of $90-199 \mathrm{~cm}^{2}$ to be big, and those of more than $200 \mathrm{~cm}^{2}$ to be very big. Mortality was estimated for the whole period and then divided by 10 to express yearly figures. 
Table 3. Transition matrices for exclosure, low grazing, high grazing, and sum of all the treatments. Cells represent transition probabilities between classes in an interval of 10 years

\begin{tabular}{cccccc}
\hline & \multicolumn{5}{c}{ Tussock state $(1989)$} \\
\cline { 3 - 6 } & & Small & Medium & Big & Very big \\
& $\left(1-39 \mathrm{~cm}^{-2}\right)$ & $\left(40-89 \mathrm{~cm}^{-2}\right)$ & $\left(90-199 \mathrm{~cm}^{-2}\right)$ & $\left(>200 \mathrm{~cm}^{-2}\right)$ \\
\hline Fate (1999) & & & & & \\
Exclosure & & 1 & 2 & 3 & 4 \\
Small & 1 & 0.423 & 0.489 & 0.248 & 0.191 \\
Medium & 2 & 0.177 & 0.177 & 0.329 & 0.285 \\
Big & 3 & 0.075 & 0.067 & 0.317 & 0.374 \\
Very big & 4 & 0.000 & 0.000 & 0.055 & 0.657 \\
Low grazing & & 1 & 2 & 3 & 4 \\
Small & 1 & 0.396 & 0.546 & 0.351 & 0.319 \\
Medium & 2 & 0.157 & 0.317 & 0.355 & 0.184 \\
Big & 3 & 0.019 & 0.133 & 0.272 & 0.204 \\
Very big & 4 & 0.004 & 0.057 & 0.189 & 0.603 \\
High grazing & & 1 & 2 & 3 & 4 \\
Small & 1 & 0.310 & 0.348 & 0.319 & 0.570 \\
Medium & 2 & 0.203 & 0.223 & 0.278 & 0.410 \\
Big & 3 & 0.061 & 0.072 & 0.300 & 0.394 \\
Very big & 4 & 0.000 & 0.003 & 0.062 & 0.381 \\
All treatments & & 1 & 2 & 3 & 4 \\
Small & 1 & 0.354 & 0.419 & 0.308 & 0.378 \\
Medium & 2 & 0.192 & 0.240 & 0.315 & 0.302 \\
Big & 3 & 0.049 & 0.097 & 0.300 & 0.321 \\
Very big & 4 & 0.002 & 0.016 & 0.109 & 0.546 \\
\hline & & & & & \\
\hline
\end{tabular}

vegetative growth. Harbered (1962) showed that modules of the same individual of the tussock grass Festuca ovina were spaced approximately $9 \mathrm{~m}$ and estimated their age as many centuries.

Projection of the demographic model shows that half the tussock population would be lost after 37 years under high levels of grazing, but standard explanations of plant mortality in rangelands do not seem to be appropriate. A rule of thumb for rangeland management indicates that consumption of as much as $50 \%$ of the standing crop allows grasses to persist (Stoddart and Smith 1955), and tussock consumption in this experimental trial has been estimated at only $13.6 \%$ under high-intensity grazing (Oliva 1996). Grazing did not even affect tussock biomass significantly, probably because compensatory growth mechanisms (McNaughton 1983) balanced that loss. Instead, increased mortality probably is related to a change in the tussock size structure, because populations under highgrazing treatments showed smaller tussocks, which in turn showed higher mortality rates regardless of grazing intensity.

Why are the tussocks smaller under high-grazing regimes? Unfortunately, the first photographic maps of the present experiment were obtained 3 years after the grazing treatments were put in place, and the initial differences could not be related unquestionably to grazing. Nevertheless, tussock subdivision could reasonably be regarded as a small-scale example of patch fragmentation, a generalized effect of grazing on landscapes (Tongway 1994). Sheep may affect tussocks during
Table 4. Dominant right eigenvalues $(\lambda)$ and corresponding population growth rates $(r)$ for 1989-1999 transition matrixes of the whole population and each of the grazing treatments.

\begin{tabular}{lcc}
\hline & $\lambda$ & $r=\ln \lambda$ \\
\hline High & 0.701 & -0.355 \\
Low & 0.876 & -0.132 \\
Exclosure & 0.794 & -0.231 \\
All treatments & 0.802 & -0.221 \\
\hline
\end{tabular}

the winter, when they trample on large tussocks in search of palatable short grasses and when, in turn, central tillers growing within senescent material are dislodged (personal observation). Occasional grazing of tussock tillers probably lowers their replacement rates, as in Agropyron desertorum (Olson and Richards 1988), and reduced density also may lead to fragmentation.

Why do small tussocks die off? In the short term, plant subdivision gives tillers access to sunlight, nutrients, and water from surrounding bare patches, thus allowing small plants to grow faster and produce more seed in favorable years. During dry spells, however, the protection of tussocks may moderate water deficit by reducing soil temperature and radiation in relation to lawn patches or bare soil, as observed by Posse et al. (2000) in Tierra del Fuego. During drought, tussocks (as well as other desert perennials) close their stomata and shed their leaves to conserve water in the basal meristems, which depend on passive uptake of water to rehydrate after drought (Westoby 1979). Exposed tillers in small plants probably dehydrate and die more easily than those that are shaded and protected from the wind in the center of big tussocks, thus increasing mortality, because plants rely on these basal meristems instead of on seeds to ensure their survival.

In the long time scale, fragmentation also may disturb the regeneration cycle of tussocks. Watt (1947) described this process in F. ovina starting with the establishment of a young tussock in bare soil in the "hollow phase." Wind-borne particles gradually accumulate in the "building phase," until a complete hummock is reached in the "mature phase." The mature tussock accumulates dead shoots and unattached roots, and it is invaded by lichens and other species in the center, thus paving the way for erosion in the "degenerate phase." Similar wind-generated patches associated with tussocks and shrubs are widespread in Patagonia, and they give rise to a dotted or "leopard" pattern, as opposed to the striped or "tiger" patches generated by water erosion (Aguiar and Sala 1999).

If tussock-originated hummocks act as traps (or sinks) of resources, then their disturbance could impair the overall productivity of the system. Examples of similar fertility patches have been found by Jackson and Caldwell (1992), who recorded higher organic matter, phosphorus, and potassium beneath tussocks of Pseudoroegneria sp. in North America; by Cerdá (1997), who found higher infiltration rates and deeperwetting fronts within tussocks of Stipa tenacissima in Spain; and by Rostagno et al. (1991), who found higher infiltration rates, porosity, nitrogen, organic carbon, phosphorus, potassium, and magnesium as well as reduced alkalinity in mounds associated with shrubs in Patagonia. Fragmentation of these patches probably implies that a large proportion of sediments, 
nutrients, partially decomposed organic matter, and seeds are blown away, because fewer sinks in the form of building-phase hummocks are present. Oliva et al. (2000) observed that the soils in high-grazing treatments of Moy Aike showed significantly fewer fine particles than did those protected from grazing. This erosion could modify, slowly and irreversibly, the environment for tussock populations and other species that exploit the uppermost soil horizons.

Our hypothesis that populations in exclosed areas would increase was not verified, because these populations showed higher subdivision and mortality rates than did those under moderate grazing. Projections showed a slow decline in tussock numbers, such that half the initial population would be left in 74 years. A plausible explanation could be that palatable short grasses were limited by grazers before the experiment and that protection from grazing enabled them to establish within the tussocks, subdividing them and increasing their mortality. In the future, grasslands in exclosed areas may stabilize as a more diverse community, with shared dominance of tussocks and other species.

\section{MANAGEMENT IMPLICATIONS}

Demographic equilibrium, a basic requirement of sustainable management, was not attained even in the moderately grazed population. Projections in this case indicate a very slow decline, halving the initial number of tussocks after 87 years of grazing. Nevertheless, that modest decrease means that no grazing regime ensures survival of tussock populations in the long run. This observation should be tested in other populations, because it may be applicable only to locations with a peripheral position in Magellanic grasslands. Only $20 \mathrm{~km}$ north of Moy Aike, tussock grasslands give way to drier, shrub-dominated vegetation. These tussock populations may be relicts established in a higher-rainfall regime or a colder climate, and a past climate change could explain their low actual demographic rates.

Our results seem to indicate that grazing modifies demographic processes of F. gracillima grasslands in a slow and persistent way, changing the size structure of the population and the patch structure of the grassland over a time scale of decades. These changes may not be perceptible for range managers until the population has been affected. Moderate stocking rates seem to be a management option to slow down (but not to stop) the process.

\section{ACKNOWLEDGMENTS}

The authors wish to thank Jorge Jamieson, owner of Moy Aike Chico, who allowed the installation of the grazing trial on his farm and helped us with its maintenance; Imanuel Noy-Meir, Juan Anchorena, and H. D. Ginzo for their critical revision that improved the paper; and Alberto Battini for his technical help in the field. Liliana Gonzalez provided cartography, and Pablo Rial aided in digitalization and image processing.

\section{LITERATURE CITED}

Aguiar, M., and 0. Sala. 1999. Patch structure, dynamics, and implications for the functioning of arid ecosystems. TREE 14:273-277.

AnCHORENA, J. 1985. Recursos naturales y aptitud de uso ganadero. Dos cartas a escala 1:40.000 para la región magallánica. In: 0. Boelcke, D. Moore, and F. Roig [EDS.]. Transecta Botánica de la Patagonia Austral. Buenos Aires: CONICET,Instituto de la Patagonia y Royal Society. p 695-733.

Boelcke, O., D. Moore, And F. Rolg. 1985. Transecta Botánica de la Patagonia Austral. Buenos Aires: CONICET, Instituto de la Patagonia y Royal Society. 733 p.

Borrelli, P., F. Anglesio, C. Baetti, M. Iacomini, and A. Ramstrom. 1988. Condición de pastizales en el sudeste de Santa Cruz (Patagonia). II: sitio "Santacrucense". Revista Argentina de Producción Animal 8(3):201-213.

Borrelli, P., C. Cheppl, M. Iacomini, and A. Ramstrom. 1984. Condición de pastizales en el sitio terraza de Río Gallegos. Revista Argentina de Producción Animal 4(9):879-897.

Borrelli, P., AND G. OLIVA. 1999. Managing grazing: experiences from Patagonia. In: D. Eldridge and D. Freundenberger [EDS.]. Proceedings of the VIth International Rangeland Congress; 19-23 July 1999; Aitkenrale, Queensland, Australia. p 441-447.

Borrelli, P., G. Oliva, M. Williams, L. Gonzalez, P. Rial, and L. Montes. 1997. Sistema regional de soporte de decisiones. Santa Cruz y Tierra del Fuego. Proyecto Prodeser. Buenos Aires: INTA-GTZ. $134 \mathrm{p}$.

Burgos, J. 1985. Clima en el extremo sur de Sudamérica. In: 0. Boelcke, D. Moore, and F. Roig [EDS.]. Transecta botánica de la Patagonia Austral. Buenos Aires: CONICET, Instituto de la Patagonia y Royal Society. p 10-40.

CASWELL, H. 1989. Matrix population models. Sunderland, MA: Sinauer Associates. $328 \mathrm{p}$.

Cerdá, A. 1997. The effect of patchy distribution of Stipa tenacissima L. on runoff and erosion. Journal of Arid Environments 36:37-51.

Collantes, M., J. Anchorena, and A. Cingolani. 1999. The steppes of Tierra del Fuego: Floristic and growthform patterns controlled by soil fertility and moisture. Plant Ecology 140:61-75.

De Fina, A., A. Garbosky, F. Gianetto, and L. Sabella. 1968. Difusión geográfica de cultivos índices en la Provincia de Santa Cruz. Publicación 111. Buenos Aires: INTA. 30 p.

FAGGI, A. 1985. Las comunidades vegetales de Rio Gallegos, Santa Cruz. In: 0. Boelcke, D. Moore, and F. Roig [EDS.]. Transecta Botánica de la Patagonia Austral. Buenos Aires: CONICET Instituto de la Patagonia (Chile) Royal Society (Gran Bretaña). p 592-633.

Harbered, D. J. 1962. Some observations on natural clones of Festuca ovina. New Phytology 61:85-100.

HARPER, J. L. 1980. Plant demography and ecological theory. Oikos 35:244-253.

HuRlbert, S. H. 1984. Pseudoreplication and the design of ecological field experiments. Ecological Monographs 54:187-211.

JaCKSON, R. B., AND M. M. CALDWELL. 1992. Shading and the capture of localized soil nutrients: nutrient contents, carbohydrates, and root uptake kinetics in a perennial tussock grass. Oecologia 91:457-462.

McNaughton, S. J. 1983. Compensatory plant growth as a response to herbivory. Oikos 40:329-336.

MOoRE, D. M. 1983. Flora of Tierra del Fuego. Livesey Limited, Shrewsbury, England: Anthony Nelson and Missouri Botanical Garden. 396 p.

OLIVA, G. 1996. Biología de poblaciones de Festuca gracillima [thesis]. Buenos Aires: Universidad Nacional de Buenos Aires, Facultad de Ciencias Exactas y Naturales. $121 \mathrm{p}$.

Oliva, G., C. Bartolomel, and G. Humano. 2000. Recuperación de vegetación y suelos por exclusión del pastoreo en la Estepa Magallánica. In: XI Conference International Soil Conservation Organization (ISCO) 22-27 October 2000; Buenos Aires. Buenos Aires: INTA.

Oliva, G., and P. Borrelli. 1993. Estepas del sudeste de Santa Cruz. In: J. Paruelo, M. Bertiller, T. Schlichter, and F. Coronato [EDS.]. Secuencias de deterioro en distintos ambientes patagónicos: Su caracterización mediante el modelo de Estados y Transiciones. Bariloche: Ludepa SME. p 5-13.

Oliva, G., A. Cibils, P. Borrelli, and G. Humano. 1998. Stable states in relation to grazing in Patagonia: a 10-year experimental trial. Journal of Arid Environments 40:113-131.

OLSON, B. E., AND J. H. RichaRds. 1988. Spatial arrangement of tiller replacement in Agropyron desertorum following grazing. Oecologia 76:7-10.

Pelliza, A., P. Willems, V. Nakamatsu, and A. Manero. 1997. Atlas dietario de herbívoros patagónicos. Somlo R. [ED.]. Bariloche: Prodesar-INTA-GTZ. 109 p. 
Posse, G., J. Anchorena, and M. Collantes. 1996. Seasonal diets of sheep in the steppe region of Tierra del Fuego, Argentina. Journal of Range Management 49:24-30.

Posse, G., J. Anchorena, and M. Collantes. 2000. Spatial micropatterns in the steppe of Tierra del Fuego induced by sheep grazing. Journal of Vegetation Science 11:43-50.

Rostagno, C. M., H. F. del Valle, and L. Videla. 1991. The influence of shrubs on some chemical and physical properties of an aridic soil in north-eastern Patagonia, Argentina. Journal of Arid Environments 20: 179-188.

Ruyle, G., and P. Ogden. 1993. What is an A.U.M.? In: Arizona Ranchers' Management Guide. R. Gum, G. Ruyle and R. Rice [eds.]. Tucson, AZ: Arizona Cooperative Extension. p 1-4.

Salazar lea Plaza, J., and R. Godagnone. 1990. Provincia de Santa Cruz. Escala 1:1.000.000. Atlas de Suelos de la República Argentina. Buenos Aires: INTA-
Secretaría de Agricultura Ganadería y Pesca. 677 p.

SAS. 1988. SAS/STAT User's guide, Release 6.03 edition. Cary, NC: SAS Institute. $1686 \mathrm{p}$.

Stoddart, L., And A. Smith. 1955. Range management. London: McGraw-Hill. 433 p.

TongwaY, D. 1994. Rangeland soil condition assessment manual. Canberra: CSIRO, Division of Wildlife and Ecology. $69 \mathrm{p}$.

WATt, A. 1947. Pattern and process in the plant community. Journal of Ecology 35:1-22.

WESTER, D. 1992. Viewpoint: replication, randomization, and statistics in range research. Journal of Range Management 45:285-290.

Westoby, M. 1979. Elements of a theory of vegetation dynamics in arid rangelands. Israel Journal of Botany 28:169-194.

Wijnhoud, S., and E. A. Sourrouile. 1972. Suelos del área Río Gallegos-Río Turbio. Bariloche: Proyecto FAO-INTA. 36 p. 